CZASOPISMO INŻYNIERII LADDOWEJ, ŚRODOWISKA I ARCHITEKTURY JOURNAL OF CIVIL ENGINEERING, ENVIRONMENT AND ARCHITECTURE JCEEA, t. XXXII, z. 62 (4/15), październik-grudzień 2015, s. 427-433

\author{
Nadezda STEVULOVA ${ }^{1}$ \\ Ivana SCHWARZOVA ${ }^{2}$ \\ EVA TERPAKOVA ${ }^{3}$ \\ Eva SINGOVSZKA ${ }^{4}$
}

\title{
OPTIMIZATION OF ORGANIC FILLER PROPERTIES BY ITS PHYSICAL TREATMENT
}

\begin{abstract}
The current trend in the construction industry is the effort to achieve sustainable development using rapidly renewable materials instead of limited ones. Need for the development of environmentally friendly products is related to the industrial interest in the use of natural plant fibres as reinforcement in composites. The attention is given to hemp fibres as a substitute for synthetic fibres due to their unique mechanical, thermal insulation, acoustic and antiseptic properties. Key problem for successful application of hemp hurds as reinforcement into composites is its high moisture sorption and its heterogeneity what lead to low cohesion of fibres to the matrix. Optimizing the adhesion of plant fibre to inorganic matrix is related to the modification of hemp surface. The objective of this paper is comparison of changes in FTIR spectras caused by combination of physical and chemical modification of hemp material with unmodified sample. Modification of hemp hurds was carried out by ultrasonic treatment and as the cleaning medium were used deionized water and $\mathrm{NaOH}$ solution.
\end{abstract}

Keywords: FTIR spectroscopy, hemp hurds, surface modification, ultrasound

\footnotetext{
${ }^{1}$ Author for correspondence: Nadezda Stevulova, Technical University of Kosice, Faculty of Civil Engineering, Vysokoskolska 4, 04200 Kosice, +421 55 6024126, nadezda.stevulova@tuke.sk.

${ }^{2}$ Ivana Schwarzova, Technical University of Kosice, Faculty of Civil Engineering, Vysokoskolska 4, 04200 Kosice, +421 55 6024278, ivana.schwarzova@tuke.sk.

${ }^{3}$ Eva Terpakovs, Technical University of Kosice, Faculty of Civil Engineering, Vysokoskolska 4, 04200 Kosice, +421 55 6024115, eva.terpakova@tuke.sk.

${ }^{4}$ Eva Singovszka, Technical University of Kosice, Faculty of Civil Engineering, Vysokoskolska 4, 04200 Kosice, +421 55 6024154, eva.singovszka@tuke.sk.
} 


\section{Introduction}

The ecological impact of new construction has become a crucial issue in recent years. Badly designed buildings guzzle natural resources and pollute their surroundings; an era of rocketing energy costs and environmental degradation, the need for sustainable, energy efficient architecture is paramount. Part of the global strategy is to use regional and recyclable, renewable materials from agro-industrial waste for civil construction. Aiming at lowering costs of households, scientific attention has been given to durable non-conventional building materials with similar features as those presented by construction materials traditionally used in civil engineering [1].

Natural fibres such as hemp, jute, sisal, bamboo, coir, kenaf and others have potential to be used as an organic reinforcement material filler in composites. The use of natural fibres and in particular hemp fibres as reinforcing agents in composite materials offers many advantages over glass fibres, such as low density, biodegradability, ecological suitability and low cost $[2,3]$. However, their incorporation in a polymer or mineral matrix involves an interface incompatibility between fibres and matrix which may be overcome with fibres pre-treatments [4]. Natural fibre is a composite in which rigid cellulose micro-fibrils are embedded in a soft matrix composed of lignin and hemicelluloses. These components of fibres influence their physical and mechanical properties $[5,6]$.

The great importance is attached to hemp plant what is a material that is rapidly renewable, carbon-negative, cost-effective and non-toxic. Excellent physical and mechanical properties of hemp predetermine its use as organic filler in building materials (lightweight composites) prepared with inorganic matrix [7]. The technical hemp (Cannabis Sativa L.) is the source of two types of fibres; bast fibres and woody fibres called hurds. The properties of hemp fibres depend on the fibre chemical composition. The bast fibres contain more amounts of cellulose compared to the hemp hurds. Contrary, contents of hemicelluloses and lignin as amorphous substances are higher in hurds [8]. The nature of plant fibres is determined by its chemical composition. In general, celluloses in natural fibres are identified as a main structural component of the fibre, which is present mainly in crystalline phase. The other components of plant fibres are hemicelluloses, lignin and pectin. Hemicelluloses and lignin present mostly in amorphous phase, which play an important role in controlling its properties. One of the key problems of plant fibres successful application is heterogeneity and hydrophility resulting in high moisture sorption sensitivity of biomaterial. Hydroxyl groups in structure of cellulose, hemicelluloses and lignin are responsible for the hydrophility of the plant material [9]. To decrease hydrophility and modify cellulosic composition of hemp fibres, chemical and/or physical [10-12] treatment of the natural material surface are applied.

The decrease of water absorbability after chemical treatment of natural fibres was proved in [13]. 
For the fibres carbohydrate degradation, Fourier transforms infrared spectroscopy (FTIR) as one of the most effective and important analytical techniques for fibrous material study is used $[14,15]$. FTIR spectroscopy provides information about molecular fragments, the presence or absence of specific functional groups.

In this paper, the results concerning FTIR study of hemp hurds after physical and physico-chemical treatment in comparison to reference sample.

\section{Materials and methods}

\subsection{Materials}

The technical hemp hurds coming from the Netherlands Company Hempflax was used in experiments. The used material was polydispersive and its density was $117.5 \mathrm{~kg} \cdot \mathrm{m}^{-3}$. This hemp hurds contains more hurds material than bast fibres.

The content of polysaccharide component (holocellulose) is $77.3 \%$. The amounts of cellulose and hemicelluloses like holocellulose components are 42.6 and $34.7 \%$, respectively. Other components present in hemp are lignin (23.7\%), compounds soluble in toluene and ethanol (2.8\%) and ash (1.8\%).

For ultrasonic cleaning process of hemp hurds surface, deionized water and sodium hydroxide (Chemapol, Slovakia, p. a.) were used.

\subsection{Treatment of hemp hurds}

Prior to treatment and in order to ensure constant humidity content, fibres were dried at $80^{\circ} \mathrm{C}$ for $24 \mathrm{~h}$ in a drying oven. Physical and physico - chemical modification of dried hemp hurds was realized by its ultrasonic treatment process for $1 \mathrm{~h}$. There were used deionized water, $0.1 \mathrm{M}$ and $0.2 \mathrm{M} \mathrm{NaOH}$ solution as cleaning medium in the experiments. In all cases of surface treatment, the s:1 (solid to liquid) ratio was 1:10. An ultrasonic bath TESON 10 (Tesla, Slovakia, $220 \mathrm{~V}, 50 \mathrm{~Hz}, 650 \mathrm{~W}$ of power output) was used for ultrasonic cleaning process of hemp hurds.

The hemp hurds samples were dried at $80^{\circ} \mathrm{C}$ after their physical treatment.

\subsection{Methods}

FTIR measurements were carried out on Bruker Alpha Platinum spectrometer with Attenuated Total Reflectance (ATR) technique (BRUKER OPTICS, Germany). Total 24 scans were performed on each sample in the range of $400-4000 \mathrm{~cm}^{-1}$. FTIR spectroscopy is capable of defecting structural changes in biomaterial. It provides information about the presence or absence of specific functional groups or formation of new functional groups and can give an even deeper insight into the fibres structure. FTIR allows identification of the main components of cellulose. 


\section{Results and discussion}

The FTIR spectra for physico - chemically treated hemp hurds samples compared to the reference sample are shown in Fig. 1. The main infrared spectral differences are observed which allow identifying the structural changes in lignocellulosic fibres after physical and physico - chemical treatment. Peak positions corresponding to vibrations of functional groups present in studied hemp hurds samples are consistent with the literature data published for vegetable fibres [14]. The range of wave number of $3570-2900 \mathrm{~cm}^{-1}$ is characteristic for stretching vibration of $\mathrm{O}-\mathrm{H}$ and $\mathrm{C}-\mathrm{H}$ bonds in polysaccharides. Based on paper [16], a broad band in the spectra range of $3490-3170 \mathrm{~cm}^{-1}$ represents the complex vibrations of hydroxyl stretching of inter - and intra-molecular hydrogen bonds. Its intensity decreases in the case of $0.2 \mathrm{M} \mathrm{NaOH}$ treatment of hemp hurds due to mercerization. The peak characteristic for waxes and oils present at $2851 \mathrm{~cm}^{-1}$ is present in all samples.

Many absorption bands corresponding to vibration of various functional groups present in hemp components are observed in the region of 1800 to $900 \mathrm{~cm}^{-1}$. This range was employed to characterize the structure of hemicelluloses, lignin, but mainly of cellulose. There are presented and discussed only the most visible differences in the spectra of treated samples compared to reference hemp hurds.

One such is the modification of the signal at $1733 \mathrm{~cm}^{-1}$, characteristic for the stretching vibration of an unconjugated $\mathrm{C}=\mathrm{O}$ group in the acetyl groups in hemicelluloses [17]. This peak has partially disappeared after treatment with $\mathrm{NaOH}$ in accordance with paper [18]. Indeed, treatment $\mathrm{NaOH}$ is known to remove hemicelluloses [19]. The peak at $1030 \mathrm{~cm}^{-1}$ belongs to $\mathrm{C}-\mathrm{C}, \mathrm{C}-\mathrm{OH}, \mathrm{C}-\mathrm{H}$ ring and side group vibrations in hemicelluloses and pectin.

Based on the observation of the sharp peaks located at $1507 \mathrm{~cm}^{-1}$ (C-C stretching from aromatic ring) in FTIR spectra, ultrasonic treatment and also with $\mathrm{NaOH}$ treatment led to a partial removal of lignin. The extraction of lignin was confirmed by high-intensity ultrasonic treatment of hemp fibres [20]. According to literature data [19], lignin cannot be totally removed by the alkaline process. As it is evident from Figure the peaks typical for lignin were clearly observed at $1319 \mathrm{~cm}^{-1}$ in all samples.

Typical bands assigned to cellulose were observed at $896 \mathrm{~cm}^{-1}$ and in the region of $1630-1160$ (Fig. 1). The absorption band at $896 \mathrm{~cm}^{-1}$ is assigned as $\mathrm{C}-\mathrm{O}-\mathrm{C}$ stretching vibration of glycosidic bonds in polysaccharides. The absorption bands assigned to cellulose at 1424 and $1373 \mathrm{~cm}^{-1}$ come from $\mathrm{CH}_{2}$ - and $\mathrm{CH}$ bending vibrations. The peaks at 1337 and $896 \mathrm{~cm}^{-1}$ represent $\mathrm{O}-\mathrm{H}$ bending vibrations in cellulose. The band about $1320 \mathrm{~cm}^{-1}$ corresponds to $\mathrm{CH}_{2}$ - wagging vibration, which distinguished between amorphous and crystallised cellulose [21]. 




Fig. 1. FTIR spectra of hemp hurds: reference (1); ultrasonic modified (2); ultrasonic modified with $0.1 \mathrm{M} \mathrm{NaOH}$ solution (3); ultrasonic modified with $0.2 \mathrm{M} \mathrm{NaOH}$ solution (4)

Rys. 1. Spektrum FTIR włókien konopnych: odniesienie (1); modyfikacja ultradźwiękami (2); modyfikacja ultradźwiękami w roztworze $0.1 \mathrm{M} \mathrm{NaOH}$ (3); modyfikacja ultradźwiękami w roztworze $0.2 \mathrm{M} \mathrm{NaOH}(4)$

\section{Conclusion}

FTIR spectroscopy of the original and treated hemp hurds shows that the physical treatment of the fibre surface has an impact on the fibre structure. Physical modification of hemp hurds by ultrasonic treatment was used as method for removal of organic and inorganic loosely bound contaminants from hemp fibres surface in the experiments. FTIR investigation of changes caused by physical and/or physico-chemical treatment of hemp hurds shows that non-cellulosic components such as hemicelluloses, lignin and waxes after hemp hurds treatment are partially removed in dependence on the cleaning medium during treatment procedure.

Whereas this physico-chemical treatment is in the initial stage of research, it is necessary to carry out more analysis (changes in chemical composition, thermal analysis, X-ray diffraction measurement) and also to study the impact of these hemp hurds treatments on the properties of biocomposites prepared with organic filler and inorganic matrix. 


\section{Acknowledgement}

The authors are grateful to the Slovak Grant Agency for financial support of the project VEGA 1/0277/15.

\section{Bibliography}

[1] Santos S.F., Tonoli G.H.D., Mejia J.E.B., Fiorelli J., Savastano Jr. H. Nonconventional cement-based composites reinforced with vegetable fibers: A review of strategies to improve durability. Materiales de Construcción Vol. 65, e041, 2015.

[2] Li Z., Wang X., Wang L. Properties of hemp reinforced concrete composites. Composites: Part A Vol. 37, pp. 497-505, 2006.

[3] Mwaikambo L.Y., Ansell M.P. Hemp fibres reinforced cashew nut shell liquid composites. Composites science and technology Vol. 63, pp. 1297-1305, 2003.

[4] Bledzki A.K., Gassan J. Composites reinforced with cellulose based fibres. Prog. Polym. Sci. Vol. 24, pp. 221-274, 1999.

[5] Poletto M.P., Zattera A.J., Santana R.M.C. Structural differences between wood species: Evidence from chemical composition, FTIR spectroscopy and thermogravimetric analysis. J. Appl. Polym. Sci. Vol. 126, e336-e343, 2012.

[6] Poletto M., Ornaghi Jr. H.L., Zattera A.J. Native cellulose: Structure, characterization and thermal properties. Materials Vol. 7, pp. 6105-6119, 2014.

[7] Faruk O., Bledzki A.K., Fink H.P., Sain M. Biocomposites reinforced with natural fibres: 2000-2010. Prog. Polym. Sci. Vol. 37, pp. 1552-1596, 2012.

[8] Gumuskaya E., Usta M., Balaban M. Carbohydrate components and crystalline structure of organosolv hemp (Cannabis sativa L.) bast fibers pulp. Bioresource Technology Vol. 98, pp. 491-497, 2007.

[9] Sreekala M.S., Kumaran M.G., Joseph S., Jacob M. Oil palm fiber reinforced phenol formaldehyde composites: Influence of fiber surface modifications on the mechanical performance. Appl. Compos. Mater. Vol. 7, pp. 295-329, 2000.

[10] Cordeiro N., Ornelas M., Ashori A., Sheshmani S., Norouzi H. Investigation on the surface properties of chemically modified natural fibers using inverse gas chromatography, Carbohydrate Polymers Vol. 87, pp. 2367-2375, 2012.

[11] Thomsen A.B., Thygesen A., Bohn V., Nielsen K.V., Allesen B., Jorgensen M.S. Effects of chemical and physical pre-treatment processes on hemp fibers for reinforcement of composites and for textiles. Ind. Crop. Prod. Vol. 24, pp. 113-118, 2006.

[12] Renouard S., Hano Ch., Doussot J., Blondeau J.P., Lainé E. Characterization of ultrasonic impact on coir, flax and hemp fibers. Mater. Lett. Vol. 129, pp. 137-141, 2014.

[13] Cigasova J., Stevulova N., Schwarzova I., Junak J. Comparison of water absorption behavior of biocomposites based on hemp hurds. Pollack Periodica Vol. 9, pp. 51-58, 2014.

[14] Fan M., Dai D., Huang B. Fourier transform infrared spectroscopy for natural fibers, Fourier Transform - Materials Analysis, InTech. pp. 45-68, 2012.

[15] Putnina A., Kukle S. STEX treated and untreated hemp fiber comparative structural analysis. Scientific Journal of Riga Technical University Vol. 6, pp. 36-42, 2014. 
[16] Carilo F., Colom X., Suňol J.J., Saurina J. Structural FTIR analysis and the thermal characterization of lyocell and viscose-type fibers. Eur. Polym. J. Vol. 40, pp. 22292234, 2004.

[17] Biagiotti J., Puglia D., Torre L., Kenny J.M. A systematic investigation on the influence of the chemical treatment of natural fibers on the properties of their polymer matrix composites. Polymer Composites Vol. 25, pp. 470-479, 2004.

[18] Liu Y. Recent progression Fourier transform infrared (FTIR) spectroscopy study of compositional, structure and physical attributes of developmental cotton fibers. Materials Vol. 6, pp. 299-313, 2013.

[19] Kostic M., Pejic B., Scundric P. Quality of chemically modified hemp fibers. Bioresour. Technol. Vol. 99, pp. 94-99, 2008.

[20] Šutka A., Kukle S., Gravitis J., Grave L. Characterization of cellulose microfibrils obtained from hemp. Conference Papers in Material Science, 2013.

[21] Fackler K., Stevanic J.S., Ters T., Hinterstoisser B., Schwanninger M., Salmén L. FT-IR imaging spectroscopy to loclise and characterise simultaneous and selective white-rot decay within sprude wood cell. Holzforschung Vol. 65, pp. 411-420, 2011.

\section{OPTYMALIZACJA WLASNOŚCI WYPELNIACZY ORGANICZNYCH POPRZEZ FIZYCZNE METODY OCZYSZCZANIA}

\section{Streszczen i e}

Obecne tendencje w branży budowlanej kładą nacisk na zrównoważony rozwój i używanie szybko odnawialnych materiałów, zamiast naturalnych ograniczonych zasobów. Potrzeba stworzenia produktów ekologicznych ukierunkowała zainteresowanie przemysłu na wykorzystanie naturalnych włókien roślinnych jako zbrojenia w kompozytach. Jako zamiennik dla włókien syntetycznych, zwrócono uwagę na włókna konopne, z powodu ich wyjątkowych cech takich jak, właściwości mechaniczny, izolacyjność cieplną i akustyczną, oraz właściwości bakteriobójcze. Kluczowym problemem pomyślnego zastosowania włókien konopnych jako zbrojenie kompozytów jest ich wysoka sorpcja wilgoci i ich heterogeniczność co powoduje niską spójność włókien z matrycą. Optymalizacja przyczepności nieorganicznej matrycy do włókien roślinnych jest powiązana z modyfikacją powierzchni włókien konopnych. Celem artykułu jest porównanie, z niezmienioną próbką, zmian obserwowanych przy użyciu spektroskopi furierowskiej FTIR, parametrów materiału konopnego spowodowanych przez łączną modyfikację materiału zarówno fizyczną jak i chemiczną. Modyfikacja włókien konopnych została przeprowadzona przez zastosowanie ultradźwięków i kąpieli w roztworze czyszczącym gdzie użyto wodnego roztworu $\mathrm{NaOH}$.

Słowa kluczowe: spektroskopia FTIR, włókna konopne, modyfikacja powierzchni, ultradźwięki

Przestano do redakcji:08.06.2015

Przyjęto do druku:10.01.2016

DOI: $10.7862 / \mathrm{rb} .2015 .207$ 